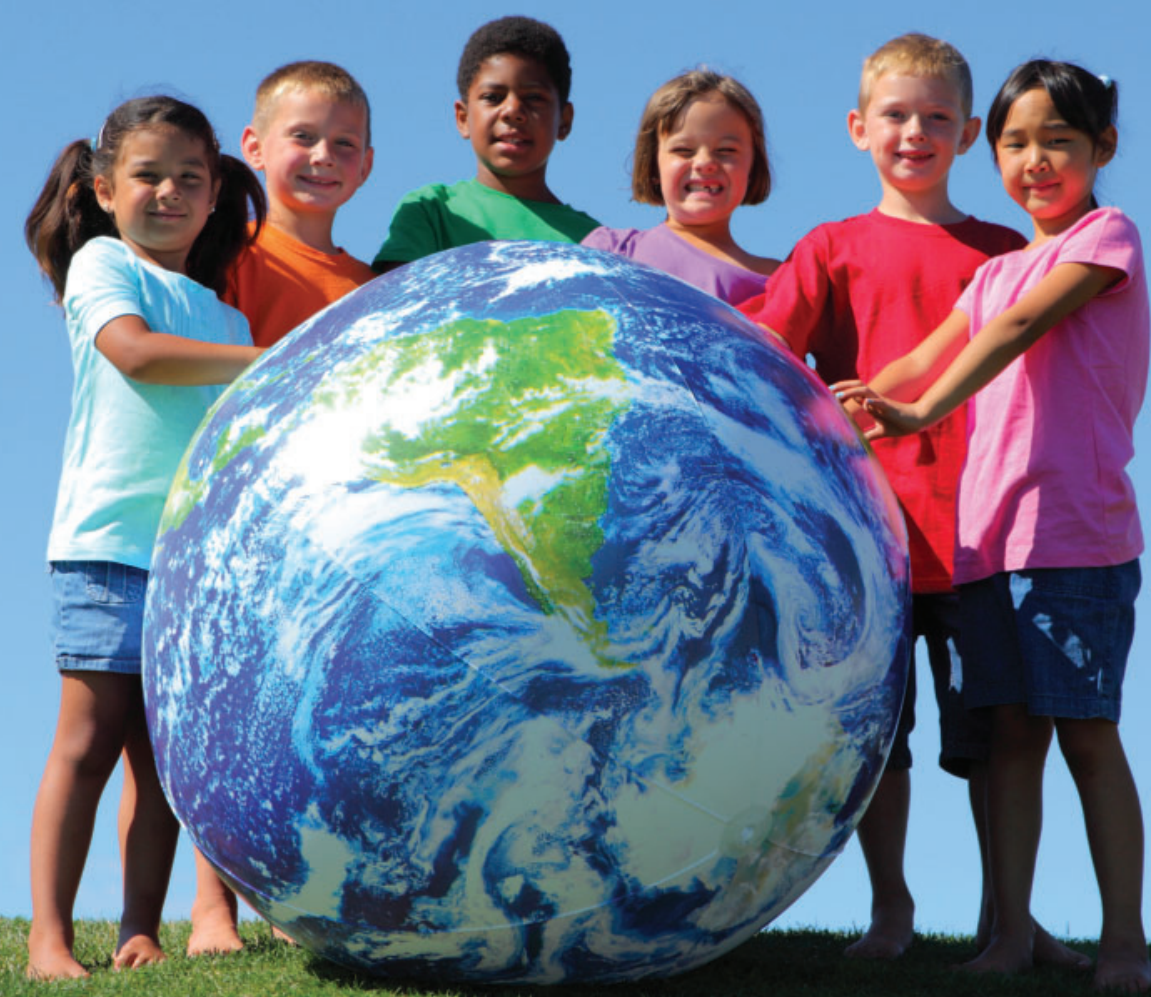

\title{
Education of migrant children
}

Education policy responses for the inclusion of migrant children in Europe

Barbara Janta, Emma Harte

RAND EUROPE 
For more information on this publication, visit www.rand.org/t/RR1655

Published by the RAND Corporation, Santa Monica, Calif., and Cambridge, UK

(C) European Union, 2016

Reproduction is authorised provided the source is acknowledged.

RAND Europe is an independent, not-for-profit policy research organisation that aims to improve policy and decisionmaking in the public interest through research and analysis. RAND's publications do not necessarily reflect the opinions of its research clients and sponsors.

RAND $^{\oplus}$ is a registered trademark.

Support RAND

Make a tax-deductible charitable contribution at

www.rand.org/giving/contribute

www.rand.org

www.rand.org/randeurope 


\section{Preface}

This policy brief was developed by RAND Europe, which in 2011 was commissioned by the European Commission's Directorate-General for Employment, Social Affairs and Inclusion to provide content and technical support for the European Alliance for Families platform, which became the European Platform for Investing in Children (EPIC) in 2013.

The European Platform for Investing in Children (EPIC) was set up to explore demographic and economic challenges in the EU from a child and family-focused perspective. Its purpose is to share the best of policymaking for children and their families, and to foster cooperation and mutual learning in the field. This is achieved through information provided on the EPIC website, which enables policymakers from the Member States to search evidence-based child-focused practices from around the EU and to share knowledge about practices that are being developed, and also by bringing together government, civil society and European Union representatives for seminars and workshops to exchange ideas and learn from each other.

RAND Europe is an independent not-for-profit policy research organisation that aims to improve policy and decisionmaking in the public interest, through research and analysis. RAND Europe's clients include European governments, institutions, non-governmental organisations and firms with a need for rigorous, independent, multidisciplinary analysis.

This document is designed to provide insights into issues of interest to policymakers and practitioners. It has been reviewed by one of EPIC's external experts in child and family policy, and internally, following RAND's quality assurance processes.

The opinions expressed do not necessarily reflect the position of the European Commission. 
RAND Policy Brief 


\section{Education of migrant children: Education policy responses for the inclusion of migrant children in Europe}

Barbara Janta and Emma Harte, RAND Europe

\section{Executive summary}

- Roughly 10 per cent of the EU population were born in a different country from the one in which they reside. Children under the age of 15 constitute five per cent of this group.

- Although the pattern varies by country, children with a migrant background (either first-, second-, or higher-order-generation migrants) show tendencies towards lower educational performance and are more likely to leave school early than their counterparts from a native background.

- Some evidence suggests that socio-economic disadvantage can have a more negative impact on educational outcomes than being from a migrant background. It is more likely that a high concentration of children from a socio-economically disadvantaged background, or from families with low educational attainment, has a greater impact on peer outcomes than a high concentration of migrant children.

- There are some solutions to the intersectional challenges faced by migrant children in education. For example, it is important to ensure that migrant students learn the language of instruction and maintain a relationship with their mother tongue, if different. In addition, it could be useful to build relationships between educators and parents, and to dedicate more resources to schools with a high concentration of migrants.

\section{Introduction}

As a result of both intra-European Union (EU) mobility and immigration from third countries, European societies have become increasingly diverse in recent decades. Some European countries have a long tradition of immigration. The UK, Germany and France, for example, experienced high growth in migrant populations after the Second World War. Migration to other countries, such as Spain, Sweden and Ireland, is a more recent phenomenon. In 2015, roughly 10 per cent of the EU population were migrants, five per cent of whom were under 15 years of age (Eurostat 2015a; Eurostat 2015b). ${ }^{1}$

This policy brief investigates policies relevant to the education of migrant children across the EU. We acknowledge that the needs of migrant children are diverse and based on a number of individual and cross-cutting factors, such as ethnic background, socio-economic background, age, age at migration, country of origin, length of stay in host country, and the migrant generation (whether one is a first-, second- or higher-order-generation migrant). As such, specific groups of migrant pupils can benefit from tailored approaches. ${ }^{2}$ Migration trends also differ between EU Member States (MS), each with different resources and tools at their disposal to respond to the diverse needs of migrants. At the same time,

\footnotetext{
${ }^{1}$ Eurostat indicator migr_pop3ctb; Eurostat indicator migr_pop3ctb_under15.

${ }^{2}$ For instance, Dumčius et al. (2013) observe that many EU countries still do not differentiate between the first- and secondgeneration of migrant children. The authors argue that migrant children would benefit if the education policies were tailored to the specific needs of these two diverse groups of migrant students.
} 


\section{RAND Policy Brief}

however, we note that this diverse group of migrant children also share many common characteristics, which can place them in a disadvantaged position vis-à-vis native children. For this reason, our review focuses on a broad range of education policies that systematically target the disadvantage faced by different groups of migrant children.

This brief also discusses the challenges facing children with a migrant background, and the individual and societal benefits to addressing such challenges. It outlines the main challenges facing migrant children in schools across Europe, and the existing policy options that aim to redress the disparities in educational outcomes between native children and children with a migrant background.

First, we briefly present the demographic situation in Europe. We then discuss the challenges of, and opportunities for, working with migrant children and explain the factors that contribute to the disadvantages they face in the education system. This is followed by a presentation of education policy responses to the growing proportion of migrant children, substantiated, when feasible, with an assessment of the effectiveness of strategies in coping with such disadvantages. We conclude by summarising how education systems have responded to the needs of migrant children and what further action may be required at the European and national levels.

\section{Migration in Europe}

\subsection{An overview of the situation}

According to 2015 Eurostat data based on country of birth, ${ }^{3}$ foreign-born residents constitute around 10 per cent of the 28-EU ${ }^{4}$ Member State population. In relative terms, the EU Member State with the highest proportion of foreign-born residents was Luxembourg, accounting for approximately 44 per cent of the total population. A high proportion of foreign-born residents is also observed in Cyprus (21 per cent), Austria (17 per cent), Belgium (16 per cent), Ireland (16 per cent), and Sweden (16 per cent).

\footnotetext{
${ }^{3}$ Eurostat indicator migr_pop3ctb (Eurostat 2015a).

${ }^{4}$ EU-28 refers to all Member States of the EU.
} 


\section{RAND Policy Brief}

Figure 1. Foreign-born population in the EU member states, 2015

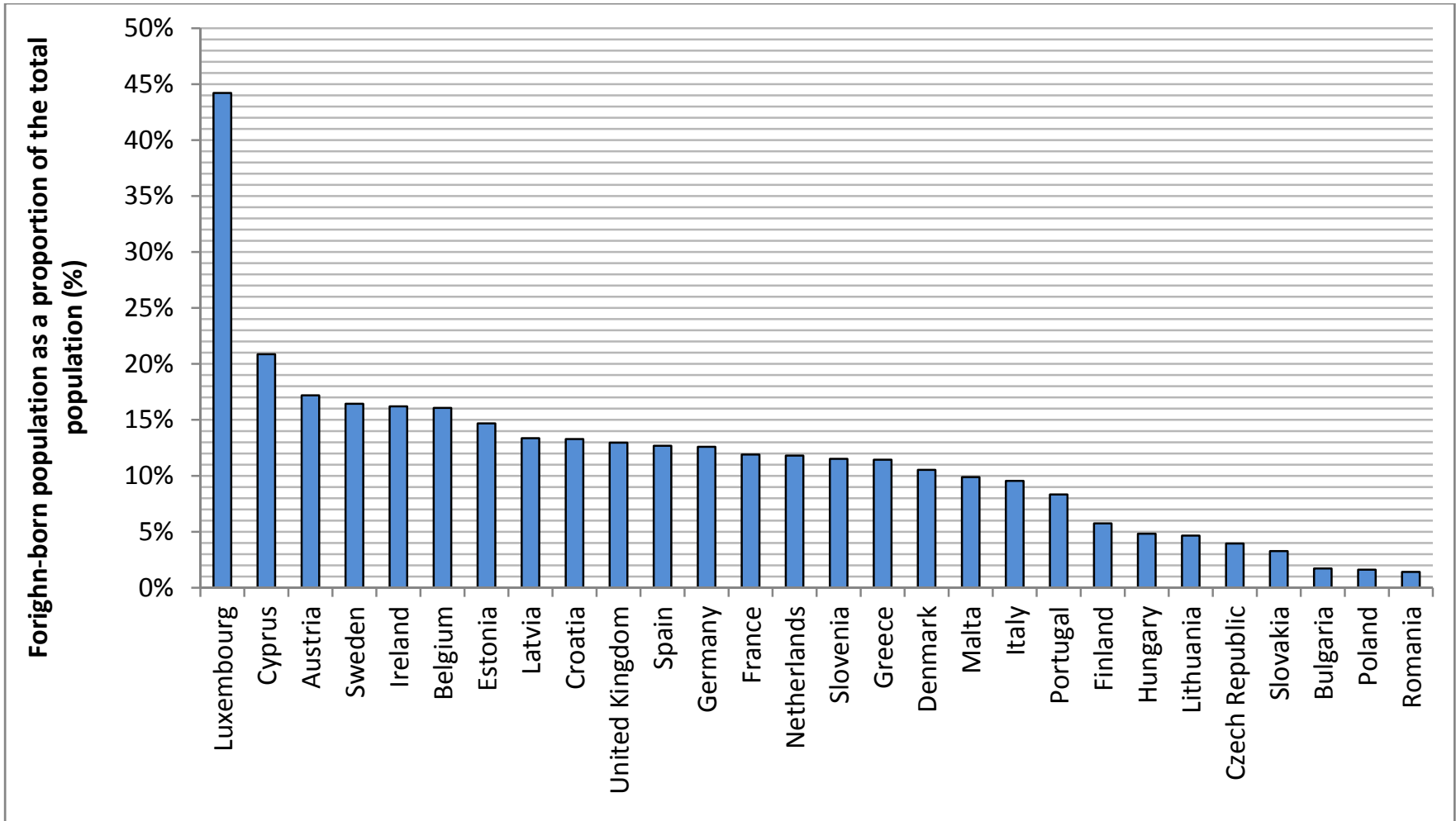

Source: Eurostat indicator migr_pop3ctb .

However, in absolute terms, the largest numbers of foreign-born residents live in Germany (10.2 million), the UK (8.4 million), France (7.9 million), Spain (5.8 million) and Italy (5.8 million) (see Figure 2).

\section{Text Box 1. Who counts as a migrant?}

Defining who counts as a migrant or a migrant child has important consequences for reporting on the number of migrants (stocks and flows), for the analysis of challenges faced by migrant populations (e.g. educational or labour market disadvantage, integration issues, discrimination) and for policies that aim to address these challenges.

There is no consensus in legal definitions and datasets used across EU countries, making it difficult to compare situations across European Union Member States. The definition of a 'migrant' (and a 'migrant child') are typically based on:

- Country of birth of parent(s) and/or child

- Citizenship/nationality of, or passport(s) held by, parent(s) and/or child

- Length of stay in a host country

- Reason for migration

- Being subject to immigration controls (Anderson \& Blinder 2015).

Most commonly, migrant status is defined either by country of birth or citizenship. Citizenship refers to the country shown on a person's passport. This can differ from country of birth. Country of birth cannot change over time, but citizenship status can change, and a second citizenship can be acquired (Tromans al. 2009).

\footnotetext{
${ }^{5}$ Eurostat indicator migr_pop3ctb.
} 
Since country of birth cannot change, Tromans et al. (2009) argue that it is a more robust variable when analysing change over time. However, it does not represent a precise proxy for international migrants as it does not take into account the length of stay in the host country. For instance, some foreign-born people could have been living in an EU country for a long time and have acquired citizenship of their host country, but they would still be counted as foreign-born (Anderson \& Blinder 2015). Consequently, country of birth data provide a collective picture of both recent migrants and of those migrants who have been resident in the host country for a number of years.

On the other hand, data based on citizenship do not necessarily provide a more accurate measure on the length of stay in the host country. For instance, there might be migrants who have arrived in a host country decades ago but have never acquired citizenship. In addition, second- and third-generation migrants, defined by many Member States as citizens of their respective countries, may still face the same disadvantages and integration problems as first-generation migrants.

Length of stay in a host country is also incorporated into some definitions. For instance, the United Nations' definition states that a long-term international migrant is a person who moved to another country for a period of at least a year (Anderson \& Blinder 2015). Being subject to immigration control is also used as a proxy for being a migrant. However, although some foreign nationals can be called migrants, not all are subject to immigration control, such as a national of an EU Member State residing in another (Anderson \& Blinder 2015).

Eurostat indicators on EU populations, social conditions and migrant integration are based on the harmonised European data sources, such as the Labour Force Survey (LFS) and the Survey on Income and Living Conditions (EU-LFS). These surveys apply a variety of definitions of migrants, and provide data based on citizenship, country of birth, long-term migrants, resident non-citizens and former citizenship. When reporting on children (the population aged 0 to 17 years), Eurostat provides data by citizenship and the country of birth of their parents.

Data on the immigrant population based on the country of birth, as explained in Text Box 1, does not account for second- and third-generation migrants. Some countries have a long tradition of immigration; for instance, in France, Germany and the UK, second- and third-generation migrants constitute a considerable number of residents.

When analysing migration data in Europe, it is important to consider migrants' countries of origin. The most basic classification divides migrants into two groups: (1) intra-EU migrants - people from other EU Member States, and (2) third-country migrants coming from non-EU countries.

EU nationals have the right to move and reside freely within the territory of the EU Member States. As a consequence, EU nationals constitute a considerable proportion of the migrant population in some countries. Examples include Slovakia (83 per cent), Luxembourg (75 per cent), Hungary (65 per cent), Cyprus (61 per cent), and Ireland (59 per cent) (Eurostat 2015a).

In other EU Member States, third-country migrants constitute a large proportion of the migrant population as a result of various historic and socio-economic factors. In some EU countries, for example France (72 per cent) and the UK (63 per cent), this trend is related to their colonial past; in others, this trend reflects labour mobility in the 1960s and 1970s, for instance guest worker migrants or 'Gastarbeiter' 


\section{RAND Policy Brief}

in Germany (61 per cent) and partly in the Netherlands ${ }^{6}$ (73 per cent). In some cases, third-country migration is because of a more recent shift in borders. For example, the majority of third-country migrants living in Estonia (93 per cent), Latvia (89 per cent) and Lithuania (86 per cent) were born in other former Soviet Union republics; similarly, many third-country migrants in Croatia (87 per cent) and Slovenia (71 per cent) were born in other former Yugoslavian republics.

The composition of migrants in other EU countries is more mixed. For instance, some southern European countries, such as Spain, Greece and Portugal, were migrant-sending countries rather than migrant-receiving countries until about two decades ago. Nowadays, however, Spain is a destination country for many migrants from Central and Southern American countries, while Italy and Greece are increasingly becoming destination countries for third-country asylum seekers and refugees (European Commission 2015). The number of immigrants arriving from outside Europe increased substantially in 2015 due to the European migration crisis (BBC News 2016).

\footnotetext{
${ }^{6}$ Most non-EU migrants in the Netherlands came either as guest workers or nationals of former colonies.
} 
RAND Policy Brief

Figure 2. Foreign-born EU and non-EU migrants in the EU member states, 2015

\begin{tabular}{|l|c|c|c|c|}
\hline EU Member State & EU migrants & $\%$ & Non-EU migrants & $\%$ \\
\hline Austria & 677,257 & $46 \%$ & 797,303 & $54 \%$ \\
\hline Belgium & 854,159 & $47 \%$ & 954,834 & $53 \%$ \\
\hline Bulgaria & 43,919 & $35 \%$ & 79,884 & $65 \%$ \\
\hline Croatia & 70,485 & $13 \%$ & 490,608 & $87 \%$ \\
\hline Cyprus & 107,372 & $61 \%$ & 69,321 & $39 \%$ \\
\hline Czech Republic & 163,473 & $39 \%$ & 252,981 & $61 \%$ \\
\hline Denmark & 202,849 & $34 \%$ & 393,027 & $66 \%$ \\
\hline Estonia & 13,253 & $7 \%$ & 179,597 & $93 \%$ \\
\hline Finland & 114,822 & $36 \%$ & 200,034 & $64 \%$ \\
\hline France & $2,184,640$ & $28 \%$ & $5,724,021$ & $72 \%$ \\
\hline Germany & $4,010,360$ & $39 \%$ & $6,210,058$ & $61 \%$ \\
\hline Greece & 345,656 & $28 \%$ & 897,268 & $72 \%$ \\
\hline Hungary & 309,596 & $65 \%$ & 165,912 & $35 \%$ \\
\hline Ireland & 445,444 & $59 \%$ & 304,499 & $41 \%$ \\
\hline Italy & $1,815,545$ & $31 \%$ & $3,989,783$ & $69 \%$ \\
\hline Latvia & 28,302 & $11 \%$ & 237,116 & $89 \%$ \\
\hline Lithuania & 19,236 & $14 \%$ & 116,785 & $86 \%$ \\
\hline Luxembourg & 185,965 & $75 \%$ & 62,923 & $25 \%$ \\
\hline Malta & 20,053 & $47 \%$ & 22,377 & $53 \%$ \\
\hline Netherlands & 532,282 & $27 \%$ & $1,464,036$ & $73 \%$ \\
\hline Poland & 218,995 & $36 \%$ & 392,860 & $64 \%$ \\
\hline Portugal & 227,716 & $26 \%$ & 637,098 & $74 \%$ \\
\hline Romania & 112,350 & $40 \%$ & 168,698 & $60 \%$ \\
\hline Slovakia & 147,923 & $83 \%$ & 29,701 & $17 \%$ \\
\hline Slovenia & 68,091 & $29 \%$ & 169,525 & $71 \%$ \\
\hline Spain & $1,981,216$ & $34 \%$ & $3,909,992$ & $66 \%$ \\
\hline Sweden & 519,215 & $32 \%$ & $1,083,307$ & $68 \%$ \\
\hline United Kingdom & $3,090,653$ & $37 \%$ & $5,320,368$ & $63 \%$ \\
\hline
\end{tabular}

Source: Eurostat indicator migr_pop3ctb.

Note: migrants defined by their country of birth. EU migrants defined as migrants from EU27 countries (exclude reporting country), non-EU migrants equal to migrants from non-EU28 countries nor reporting country.

\subsection{Migrant children in Europe}

Migrant children constitute a considerable proportion of the total population under 15 years of age in EU Member States (see 
RAND Policy Brief

Figure 3). Definitions are nuanced and varied, and sometimes do not distinguish between first-, secondor higher-order-generation migrants. The following section provides an overview of some of these working definitions. 


\section{RAND Policy Brief}

\section{Text Box 2. Definitions of 'migrant child'}

The term 'migrant child' can refer to two groups of children:

1. children born abroad within or outside the EU (first-generation migrants)

2. children whose parents were born abroad or who have one parent who was born abroad (secondgeneration migrants).

In relation to migrant children, education policies in several Member States also distinguish between children whose first language is different from the majority language in a host country and native speakers of the language of a host country. For instance, in England, children whose first language is not English are defined as 'speakers of English as an Additional Language'.

Some countries (e.g. France) also define migrant children by the country of birth and/or nationality of their parents and grandparents. For instance, French statistics provide data on children who have at least one parent who was not born in France as well as children born to non-French citizens. The data are used to determine the population of second- and third-generation migrant children (Breuil-Genier et al. 2011; Insee 2011).

These various definitions of migrants have implications for different estimates of the number of migrants and the impact of migration on the host societies (e.g. on the education and health systems, labour market, etc.), as well as public and policy debates on these topics.

Migrant children (first-generation) constitute approximately 4 per cent ${ }^{7}$ of the under-15 EU population (excluding Germany) but the situation varies considerably between Member States. The highest shares of migrant children under 15 years of age (as a proportion of all children under 15 years of age) are found in Luxembourg (19.5 per cent), Ireland (9.8 per cent), Cyprus (9.1 per cent), Sweden (7.3 per cent), Belgium (7.2 per cent), Austria (6.6 per cent), the UK (5.5 per cent) and Spain (5 per cent) (Eurostat, data for 2015). EU-born children constitute the largest proportion of the EU migrant child population in Luxembourg (13.6 per cent), followed by Cyprus (7 per cent), Ireland (5.4 per cent), Belgium (4.2 per cent) and Austria (3.2 per cent) (Eurostat, data for 2014). Among the foreign-born population, there are disparities in the age composition between EU Member States; for instance, children make up 37.8 per cent of the migrant population in Romania, 27.1 per cent in Bulgaria, 13.4 per cent in Ireland, 10.8 per cent in Slovakia, and 10.7 per cent in Poland.

\footnotetext{
${ }^{7}$ Data on migrant children under the age of 16 were not available in Germany.
} 
RAND Policy Brief

Figure 3. Foreign-born children in the EU Member States, 2015

\begin{tabular}{|l|c|c|c|c|}
\cline { 2 - 5 } \multicolumn{1}{c|}{} & \multicolumn{2}{c|}{$\begin{array}{c}\text { Migrant children less than 15 } \\
\text { years old }\end{array}$} & \multicolumn{2}{c|}{$\begin{array}{c}\text { EU migrant children less than 15 } \\
\text { years old }\end{array}$} \\
\hline EU Member State & $\begin{array}{c}\text { Migrant } \\
\text { children }\end{array}$ & $\begin{array}{c}\text { \% of total under } \\
15 \text { population }\end{array}$ & $\begin{array}{c}\text { EU migrant } \\
\text { children }\end{array}$ & $\begin{array}{c}\text { of total } \\
15 \text { population }\end{array}$ \\
\hline Austria & 80,971 & $6.6 \%$ & 42,572 & $3.5 \%$ \\
\hline Belgium & 138,247 & $7.2 \%$ & 81,968 & $4.3 \%$ \\
\hline Bulgaria & 33,563 & $3.4 \%$ & 23,298 & $2.3 \%$ \\
\hline Croatia & 9,789 & $1.6 \%$ & 4,216 & $0.7 \%$ \\
\hline Cyprus & 12,715 & $9.1 \%$ & 8,947 & $6.4 \%$ \\
\hline Czech Republic & 15,290 & $1.0 \%$ & 4,633 & $0.3 \%$ \\
\hline Denmark & 42,264 & $4.4 \%$ & 15,571 & $1.6 \%$ \\
\hline Estonia & 4,118 & $2.0 \%$ & 2,102 & $1.0 \%$ \\
\hline Finland & 29,923 & $3.3 \%$ & 12,448 & $1.4 \%$ \\
\hline France & 453,537 & $3.7 \%$ & 154,924 & $1.3 \%$ \\
\hline Germany & No data & No data & No data & No data \\
\hline Greece & 45,996 & $2.9 \%$ & 17,131 & $1.1 \%$ \\
\hline Hungary & 41,314 & $2.9 \%$ & 26,653 & $1.9 \%$ \\
\hline Italy & 314,339 & $3.7 \%$ & 105,497 & $1.3 \%$ \\
\hline Ireland & 100,495 & $9.8 \%$ & 52,683 & $5.1 \%$ \\
\hline Latvia & 6,036 & $2.0 \%$ & 4,224 & $1.4 \%$ \\
\hline Lithuania & 11,276 & $2.7 \%$ & 7,903 & $1.9 \%$ \\
\hline Luxembourg & 18,321 & $19.5 \%$ & 12,926 & $13.8 \%$ \\
\hline Malta & 2,568 & $4.2 \%$ & 1,141 & $1.9 \%$ \\
\hline Netherlands & 107,888 & $3.8 \%$ & 44,932 & $1.6 \%$ \\
\hline Poland & 65,482 & $1.1 \%$ & 49,560 & $0.9 \%$ \\
\hline Portugal & 38,512 & $2.6 \%$ & 16,943 & $1.1 \%$ \\
\hline Romania & 106,345 & $3.5 \%$ & 84,167 & $2.7 \%$ \\
\hline Slovenia & 10,524 & $3.5 \%$ & 2,498 & $0.8 \%$ \\
\hline Slovakia & 19,239 & $2.3 \%$ & 15,809 & $1.9 \%$ \\
\hline Spain & 354,146 & $5.0 \%$ & 101,136 & $1.4 \%$ \\
\hline Sweden & $7.3 \%$ & 29,402 & $1.7 \%$ \\
\hline United Kingdom & $5.5 \%$ & 300,246 & $2.6 \%$ \\
\hline Sorce: & & & \\
\hline
\end{tabular}

Source: Eurostat indicator migr_pop3ctb.

Note: migrant children defined by their country of birth. EU migrant children defined as migrant children from EU27 countries (exclude reporting country). No 2015 data for Germany.

Diversity is reflected in the education system. In some urban areas, such as Rotterdam, Birmingham, Brussels or Vienna, half of the pupil population in certain schools are migrant children (first- and secondgeneration inclusive) (DG EAC 2009; OECD 2010).

Proficiency in the host country's language for migrant children tends to be below average. In England, the percentage of children aged 5-16 in primary and secondary schools who have English as an Additional Language has more than doubled from 7.6 per cent in 1997 to 16.2 per cent in 2013 (Strand et al. 2015). The situation varies widely across the English regions, with some localities recording a much higher share 


\section{RAND Policy Brief}

of speakers of English as an Additional Language. For instance, 43 per cent of school children in outer London, 56 per cent in inner London, 58 per cent in Slough, 51 per cent in Luton and 49 per cent in Leicester have a first language other than English (Strand et al. 2015).

When female migrants give birth in their host country they also contribute to the growth of the migrant population. For instance, in 2010 in metropolitan France, 27.3 per cent of newborns had at least one foreign-born parent, including 23.9 per cent that had at least one parent born outside of Europe. The 2010 figures represent a 4.1 per cent increase compared with 1998 when 23.3 per cent of newborns had at least one parent not born in France (Insee 2011). In addition to country of birth, the French statistical authority also provides data for births to French citizens. Since some of the non-French born parents were naturalised French citizens, the proportions of children born to non-French citizens is smaller, with 80.1 per cent of newborns in 2010 having two French parents, 13.3 per cent having one French parent and 6.6 per cent having two non-French parents (Insee 2011). Nevertheless, this is an increase over the last decade as 85.5 per cent of all newborns had two French parents in 1998. There is also some information available on the second and third generation of migrant children. For instance, it was recorded that between 2006 and 2008, about 40 per cent of newborns in France had one foreign-born grandparent (Breuil-Genier et al. 2011).

In England and Wales, the proportion of births to non-UK born women has also been steadily increasing, from 15.3 per cent in 2001 to 26.5 per cent in 2013 (ONS 2014; Tromans et al. 2009; Zumpe et al. 2012). There are three main factors that contributed to this increase: 1) an increase in the number of migrant women of childbearing age; 2) the different age structures of the migrant women and UK born populations of reproductive age; and 3) higher fertility (Total Fertility Rates, TFR) among migrant women. With respect to the TFR among migrant women compared with UK-born women, Zumpe et al. (2012) and Robarts and Berrington (2015) note a convergence in fertility trends. The TFR of migrant women tend to decrease with the duration of their stay in the UK. For that reason Robards and Berrington (2015:i) suggest that 'aggregate measures of fertility based on period TFRs may not be a useful indicator of the likely completed family size that migrant women will have at the end of their reproductive lives.'

The convergence in fertility trends among migrant women has also been reported by other authors. For instance, a study by Kulu and González-Ferrer (2014) shows that the TFR of migrant women in Europe tends to converge with those of natives within one generation of living in the European country. However, as the authors note, the fertility rates of first- and higher-order-generation migrants from some countries (e.g. from Pakistan and Bangladesh living in the UK, and populations of Turkish background living in France) remain significantly higher than the native population.

With this rising share of children to mothers born abroad, the challenge of integrating migrant children in the European education systems and wider societies will only increase in the coming decades. As summarised by Arnot (2014), '[Migrant children's] presence in a school highlights the degree to which compassion, caring and justice shape our education system.'

\subsection{What the literature says about migrant children in Europe}

Studies examining the education of migrant children have focused on various groups of migrant children. For instance, a study by Dumčius et al. (2013) has focused on newly arrived migrant children (first- 


\section{RAND Policy Brief}

generation), whereas reports by Crul and Schneider (2009) and Szalai (2011) provide evidence on the second- (and to some extent the third-) generation children with ethnic minority backgrounds in selected European countries. This focus on clearly defined groups of migrant children allowed the authors to identify specific challenges that these children are facing and to provide specific recommendations relevant for particular groups of children.

Data from the Programme for International Student Assessment (PISA) and the Progress in International Reading Literacy Study (PIRLS), from the Organisation for Economic Co-operation and Development (OECD) show a variety of parameters relevant for migrant children. Some of the data and analysis do not distinguish between first- and second-generation migrant children, e.g. the data pertain to students with an immigrant background, including children of immigrant parent(s) and children who immigrated as a child. However, more detailed information on the specific characteristics of migrant children is also provided. For instance, this includes analyses of:

- Children of immigrant parent(s) defined by their place of birth, e.g. students with an immigrant background with parents from OECD and non-OECD countries (second generation of migrant children).

- Foreign-born migrant children with two immigrant parents by child's age of arrival to the host country (first-generation). ${ }^{8}$

- Students with immigrant status by language spoken at home (first- and second-generation migrant children).

In this way, the OECD data allow individuals to analyse trends for particular groups of migrant children and to identify challenges that particular groups of children are facing.

However, some of the literature does not distinguish between particular groups of migrant children (see for instance Heckmann (2008), Brind et al. (2008) and Eurodiaconia (2014)). The reports often use a generic category of 'migrant children' and use synonymous terms like 'immigrant students' (firstgeneration) and 'children of (im)migration background'/'ethnic minority' students (second-generation). In this way, the authors take a comprehensive approach covering a wide range of issues relevant to migrant children. On the other hand, as the studies do not distinguish between particular groups of migrant children, some specific challenges and policy solutions relevant only to particular groups of migrant children are not clearly differentiated.

This policy brief discusses the education needs of both groups of children, namely first- and secondgeneration migrant children. In this way, it relates to newly-arrived migrant children and to children with a migrant background (with one or both parents born abroad). When discussing particular challenges and potential policies to address these challenges, we aimed to specify which group(s) of children these challenges and policies pertain to wherever possible. However, this was not always feasible when reviewed sources did not provide this distinction in their analysis of migrant children.

\section{Challenges faced by migrant children}

\footnotetext{
${ }^{8}$ Children who were born in the host countries and who have at least one parent who was born in this country are considered 'native' in OECD publications. See for instance Nusche (2009).
} 


\section{RAND Policy Brief}

In this section, we discuss the different challenges faced by migrant children and the evidence that highlights the different dimensions of these challenges. These challenges, often complex and intersectional, include issues such as socio-economic disadvantage, language, native culture bias and attainment. This section seeks to understand these challenges in order to understand how existing policy options work towards addressing them.

\subsection{Educational attainment}

Across European countries, statistics show that, on average, migrant children have a significantly lower level of academic achievement than children with two native-born parents. According to Heath et al. (2008), this disadvantaged position of migrant children vis-à-vis children with both native parents can be caused by: (1) having access to fewer socio-economic resources, including the lower academic achievement of their parents; and (2) even after accounting for this lack of resources, migrant children suffer from a negative penalty associated with migratory status. Some challenges faced by migrant children result from the characteristics of migrant groups, e.g. low socio-economic status, knowledge of a local language, psychological barriers, potential low expectations from parents and teachers, ${ }^{9}$ as well insufficient family and community support.

The OECD's analysis of the PISA data shows that a high concentration of migrant children in a school or class is not necessarily a factor that could hinder other students' performance. It is more likely that a high concentration of children from families with lower socio-economic status and educational attainment impacts negatively on educational performance (OECD 2015; Jensen 2015). The OECD (2015) illustrates this point by stating that 21 per cent of all students in the US have a migrant background, while 40 per cent of students in disadvantaged areas have a migrant background. PISA data (OECD 2015) show that the presence of migrant students does not have a strong association with student performance. Similarly, the presence of a large number of children with low-educated parents (in particular the mother) has a far greater impact on the overall school achievement of students than the presence of a large number of migrant children in a class or school (Nusche 2009; OECD 2010). For that reason, OECD researchers $(2010 ; 2013)$ suggest that governments should progress towards more mixed classrooms in terms of students' socio-economic background rather than in terms of their migration status. Similar conclusions are drawn by Heckmann (2008), who shows that the presence of children with high educational aspirations and good academic performance has a substantial influence on the achievement of migrant children. The benefits of mixed classrooms are twofold: first, they help students to achieve better academic outcomes; second they encourage social inclusion.

Other challenges are linked to the organisational aspects in which support takes place, e.g. curriculum bias valuing majority culture; a strong cultural bias in assessment tests; limited funding opportunities for the provision of support; a clustering of migrant students in underperforming schools and the referral of migrant children to special education schools or lower-ability tracks (e.g. vocational education); and inadequate levels of responsiveness from the state and other regional and local actors.

\footnotetext{
${ }^{9}$ On the other hand, some studies show that migrant parents can have high academic aspirations towards their children, e.g. Cebolla et al. (2013). This, in turn, can potentially increase the level of academic achievement reached by migrant children.
} 


\section{RAND Policy Brief \\ 3.2. Command of the local language}

Limited or no command of the host society language is the most common barrier for migrant integration and educational success; poor language skills limit migrant parents' opportunities to support their children in their learning. A study by Crul and Schneider (2009) focusing on second-generation migrant children shows that migrant parents mostly offer socio-emotional support rather than practical support. Analysing the situation of the first generation of migrant children, Dumčius et al. (2013) observe that language barriers also restrict migrant parents' ability to engage with the wider school life (e.g. through being involved in parents' committees, contributing to school activities) and in communication with service providers.

Migrant children (both first- and second-generation) starting school without the knowledge of a host country language are in a disadvantaged position vis-à-vis native pupils, and their learning is often hindered until they overcome the language barrier (OECD 2010). Secondary analysis of PISA data has highlighted disparities in attainment levels between first- and second-generation migrant students who speak the language of instruction at home, and those who do not. The results show that those who do not speak the language of instruction at home score lower on reading and mathematics than those who do. Nonetheless, migrant children who do speak the language of instruction at home still tend to score lower on the same tests than native students. Brind et al. (2008) suggest that this lower level of attainment in cases where the language of instruction is not spoken at home could be due to lower levels of parental integration, and thus a lack of parental engagement with the school, coupled with students' lack of personal familiarity with the instructional language. However, these differences in attainment are not exclusively linked to speaking a different language from the language of instruction, and socio-cultural factors might also play a role (Brind et al. 2008). For example, cognitive academic language proficiency (CALP), a 'decontextualised language use [...] common in school subjects,' is suggested as an important factor for attainment (Brind et al. 2008, 37). Other studies, however, are more positive in their outlook. De Paola and Brunello (2016), for example, show that attainment in mathematics among students who do not speak the language of instruction at home varies depending on the country. ${ }^{10}$ Research from the UK examining educational attainment among 5-16 year olds has shown that, despite performing less well than native students prior to starting school, ethnic minority children 'catch up during their school career,' mainly as a result of language acquisition (De Paola and Brunello 2016, 19; Dustmann et al. 2012).

\subsection{Social isolation}

A Eurodiaconia (2014) report lists psychological factors, such as feelings of isolation, exclusion, or prejudice, as challenges for migrant families. These psychological factors can limit the level of trust migrants have in other people. This, in turn, can further reinforce feelings of worthlessness and hopelessness, and can induce passivity and a lack of incentives to make efforts to change their lives. Eurodiaconia also noted that the feeling of hopelessness can be reinforced by material deprivation and

\footnotetext{
${ }^{10}$ Based on PISA, TIMMS and PIRLS, there were considerable gaps in attainment. Children who did not speak the language of instruction at home tended to do considerably less well in Finland, Germany, Belgium and France; smaller gaps were noted in the UK and the US; and in Australia, for example, students who did not speak the 'native' language at home performed better than students who spoke the language of instruction.
} 


\section{RAND Policy Brief}

poor living conditions. Other challenges to migrant children's integration identified in the Eurodiaconia (2014:8) report include authorities' 'insufficient awareness' of migrant children's needs and a lack of funding sustainability, with the limited financial capacity of service providers restricting the scope and range of services and their stability.

As a result of these challenges, migrant students tend to have lower levels of academic performance, higher early-school leaving rates and are over/underrepresented in certain school types vis-à-vis native students on aggregate. Migrant students are also more likely than native students to obtain lower levels of qualifications and less likely to progress into higher education. They are also more likely to experience marginalisation and exclusion (Brind et al. 2008; Heckmann 2008; OECD 2010).

\subsection{Educational disadvantage and early school leaving}

Data reveal differences between migrant students and native pupils' in levels of educational attainment. Findings from comparative studies, such as the OECD's PISA, show that, on average, immigrant pupils achieve lower educational attainment compared with native pupils. ${ }^{11}$ With the exceptions of Slovakia and Hungary, immigrant students score lower in reading as well as in mathematics (see Figure 4 and

\footnotetext{
${ }^{11}$ On the other hand, some groups of migrant pupils consistently have higher levels of attainment than other groups. For instance, the UK Department for Education and Skills (2006) study focusing on the minority ethnic pupils (first and second generation migrant children) aged 5 to 16 in maintained (state) primary and secondary schools in England and Wales found that Indian, Chinese, Irish and some White and Asian pupils overall reach higher levels of education than other minority ethnic pupils and the native population. The higher levels of attainment are found across all the Key Stages of primary and secondary schooling. On the other hand, Gypsy/Roma, Traveller of Irish heritage, Black, Pakistani and Bangladeshi pupils consistently have lower levels of attainment than other ethnic groups across all the Key Stages. Pupils' attainment can be linked to the wider range of factors such as social class and education of parents, motivation for migration and how the value of education is perceived by these groups of migrants.
} 


\section{RAND Policy Brief}

Figure 5 below). Analysing PISA results, Jakubowski (2011) noted that the socio-economic background of students explains only part of the performance gap. His analysis shows that even after accounting for socio-economic status, in most countries immigrant students still lag behind native students in academic performance, and in many countries these differences are significant.

Figure 4. Reading performance of native students and students with an immigrant background, PISA 2000 and 2009

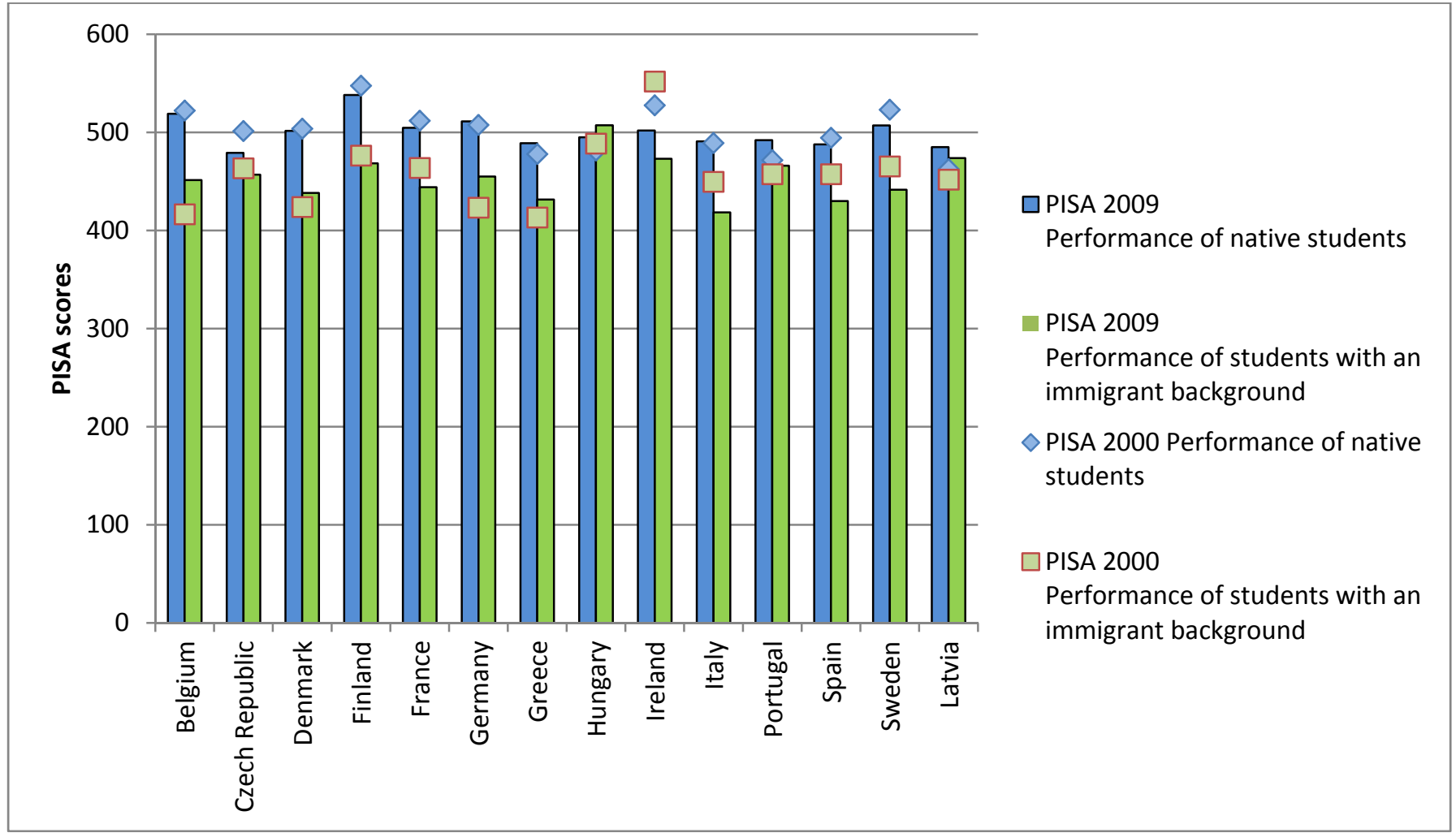

Source: Adapted from OECD PISA data 2011.

Note: Only EU countries with data for both 2000 and 2009 are presented. Missing data for the following EU Member States: Austria, Bulgaria, Luxembourg, the Netherlands, Poland, Romania and the United Kingdom. Immigrant students defined as those with an immigrant background, which means they can be either first generation (those who are foreign-born and whose parents are also foreign-born) or second-generation (those who were born in the country of assessment but whose parents are foreignborn). 
Figure 5 Difference in mathematics performance between native and immigrant students, PISA 2012

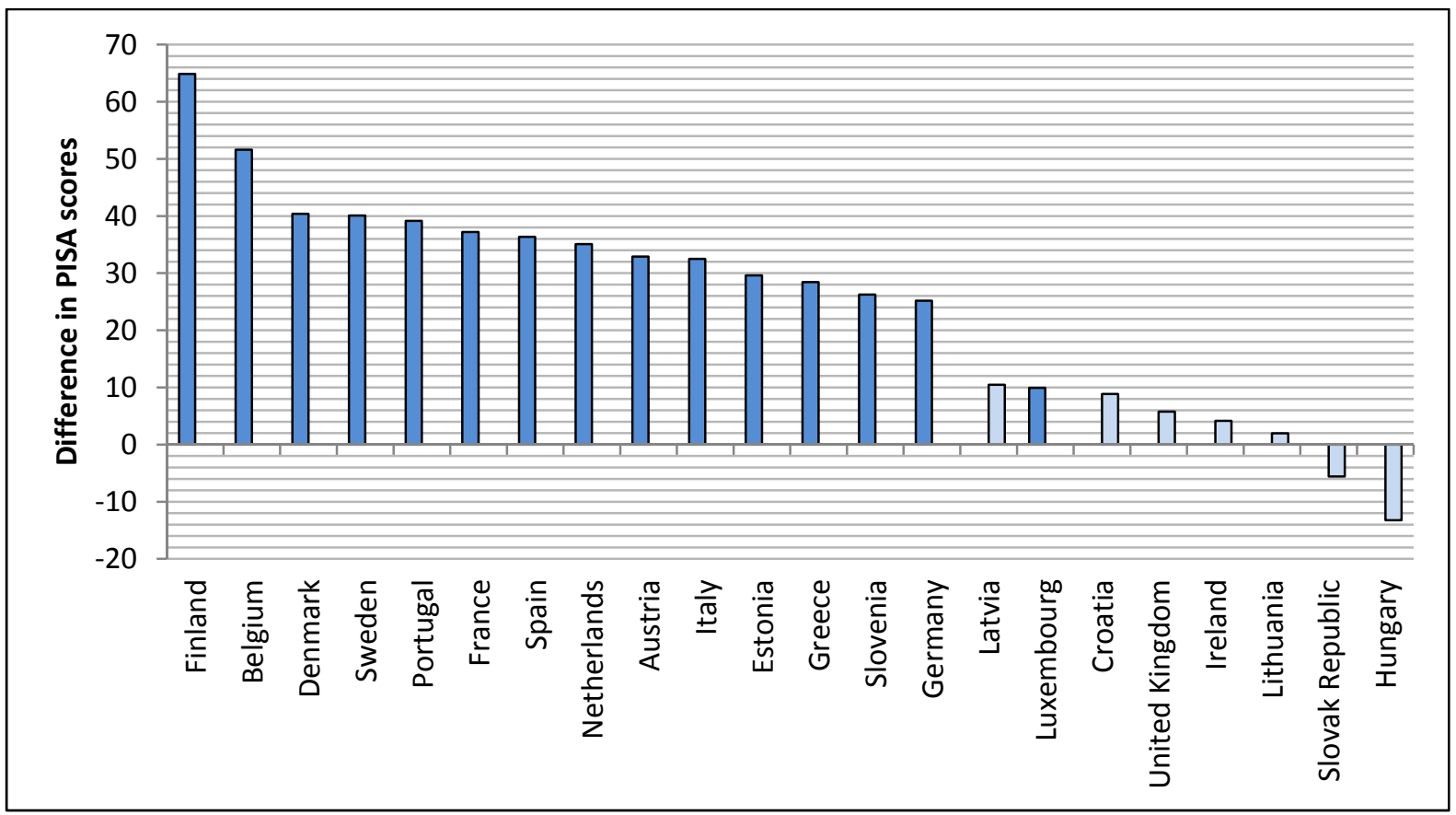

Source: Adapted from OECD PISA 2012 Database, Table II.3.4a.

Note: Score-point differences that are statistically significant are marked in a darker tone. Countries are ranked in descending order of the score-point difference between native and immigrant students, after accounting for socio-economic status. Only EU countries with data for 2012 are presented. Data are missing for Czech Republic. Immigrant students defined as those with an immigrant background, which means they can be either first generation (those who are foreign-born and whose parents are also foreign-born) or second-generation (those who were born in the country of assessment but whose parents are foreign-born).

Nevertheless, the disadvantaged situation of migrant students and their educational outcomes can be improved when challenges to migrant education as well as wider integration are addressed. Cross-country comparative studies, such as Fossati (2011), Schneeweis (2011) and Dustmann et al. (2012) found that the differences between the educational outcomes of children of immigrants and native students can be explained by the history of immigration to particular EU countries. In countries with a long tradition of immigration, such as the UK, the authors did not find significant differences between immigrant and native students' school results. However, the achievement gaps were significant and substantial in Nordic and Continental European countries. The authors argue that these results suggest there is scope for learning from other countries that have long been addressing challenges related to the integration of migrant children in the education systems. On the other hand, these results could be challenged by the different composition of immigrant populations in particular EU countries, as well as results from other studies (e.g. the Department for Education and Skills 2006 report) showing consistent differences in the level of attainment between migrant and native pupils.

Algan et al. (2010), examining the integration of immigrants and their children in France, Germany and the United Kingdom, find that the children of immigrants do worse than the children of native-born parents. However, children of immigrants often do better than their own parents. The authors concluded that this suggests that education systems are working to integrate immigrant children 'though it is much harder to say whether progress is as fast as it could be' (Algan et al. 2010:25).

This evidence suggests that underachieving migrant pupils can improve their outcomes and do relatively well with the right educational setup and wider integration policies. In the next part of this paper we 


\section{RAND Policy Brief}

discuss how the challenges in the education system can be addressed to provide opportunities for all students to reach their full potential.

It appears that children with a migrant background are disproportionately represented among early school leavers and the lower performing percentiles (Nouwen et al. 2015). Young migrants are also more likely to fall into the NEET category (people not in education, employment, or training) (see Figure 6).

Figure 6. Young people (15-24) not in education, employment or training (NEETs) by country of birth, 2015.

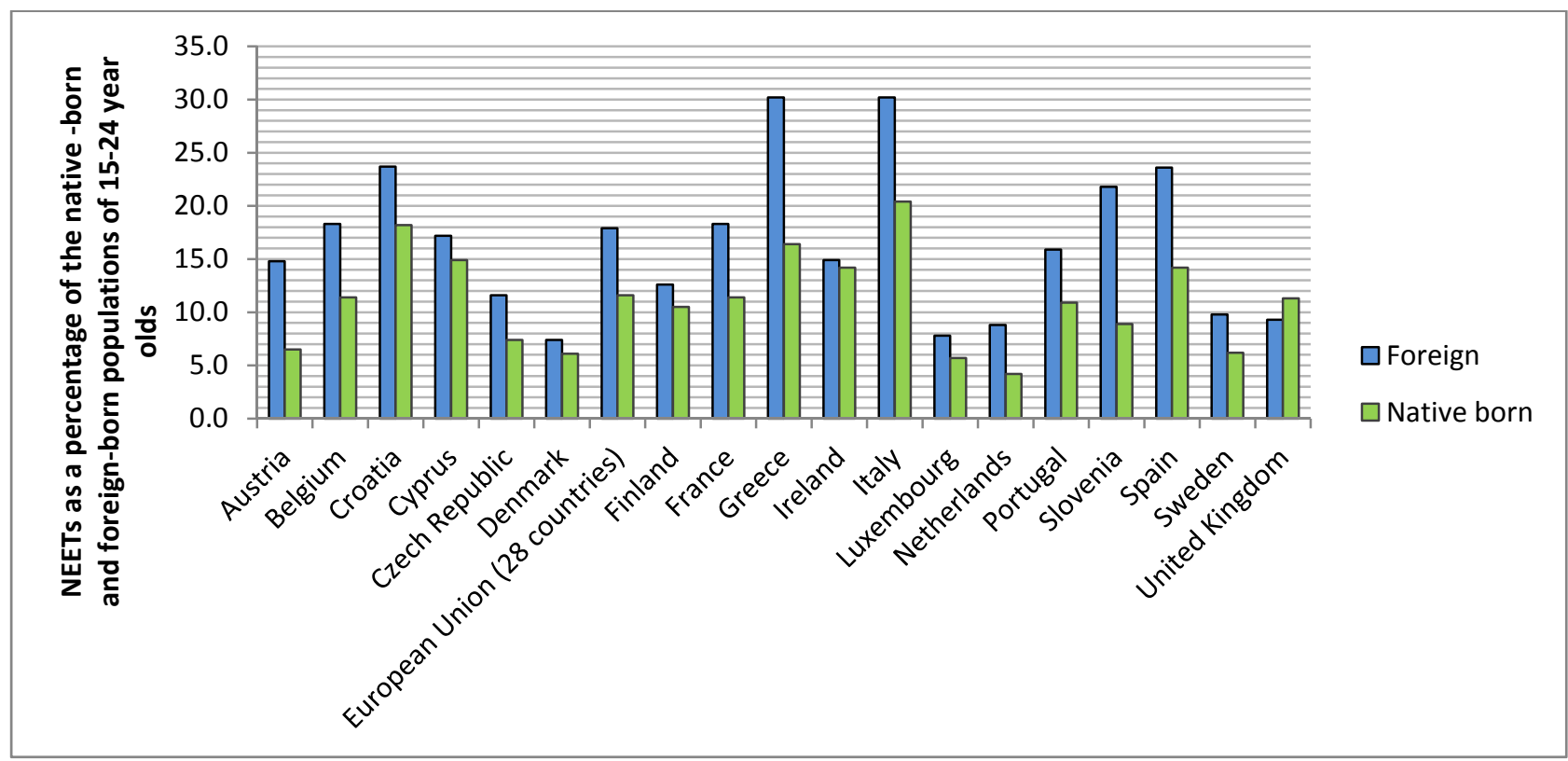

Source: Eurostat, variable Young people neither in employment nor in education and training by sex, age and country of birth (NEET rates) [edat_lfse_28].

Note: Data not available for Bulgaria, Estonia, Germany, Hungary, Latvia, Lithuania, Malta, Poland, Romania and Slovakia.

\section{Policy responses to the education of and wider support for migrant children}

In 1977, the Council of the European Union adopted a Directive ${ }^{12}$ on the education of children of migrant workers that initiated a series of actions aimed towards establishing support measures for children with a migrant background. These actions focused on the integration of migrant pupils through the provision of equitable education and training systems, the prevention of school failure and the improvement of educational achievements of learners with a migrant background. ${ }^{13}$ The most recent European Commission Green Paper, entitled 'Migration and mobility: challenges and opportunities for EU education systems', and the report on the public consultation that accompanied the Green Paper, put emphasis on the education policy for children with migrant backgrounds, the related policy challenges, and how these challenges can be tackled at the national and European levels. ${ }^{14}$ The European

\footnotetext{
12 77/486/EEC

${ }^{13}$ For instance, compare with the conclusions of the Council and the Representatives of the Governments of the Member States on the establishment of common basic principles for immigrant integration policy in the European Union (Doc. 16238/1/04 REV1 and Doc. 15252/08) and to ensure equitable education and training systems (OJ C 298, 8.12.2006); Decision No 1720/2006 of the European Parliament, the European Council conclusions (7652/08).

${ }^{14}$ Commission of the European Communities, Green Paper 'Migration and mobility: challenges and opportunities for EU education systems, $\operatorname{COM}(2008) 423$ final, \{SEC(2008) 2173\}.
} 


\section{RAND Policy Brief}

Commission recognises the challenges facing migrant children in integrating and succeeding in host country education systems, and in the wider socio-economic integration of migrant populations.

Beyond the EU level, several studies have characterised policies that facilitate the inclusion of migrant children and alleviate their disadvantage in the education system and later in life. Various typologies for characterising these policies have been proposed (compare inter alia Dumčius et al. 2013; Heckman 2008; Nusche 2009), some focusing on a wide range of factors influencing students' educational success, and others looking solely at education policies.

Nusche $(2009 ; 6)$, for instance, organised a framework on education policies principally across three levels: the system, school and individual levels. System level policies are structural features of education systems such as school choice, tracking, selection mechanisms and resource inequalities. At the next level, the school policies are individual measures that shape school and classroom environments as well as school-home relationships such as teacher expectations, classroom environments and school organisation. Finally, policies which focus on individual student characteristics relate to factors such as socio-economic background and language proficiency.

Paying specific attention to educational support for newly-arrived migrant children, Dumčius et al. (2012:5) state that an integrated approach to inclusion is important. The authors note that 'policy makers should pay more attention to the overall structure of the education systems and its effects on the newly arrived migrant children's inclusion rather than the individual support measures' targeted at these children. The proposed integrated approach to making a more inclusive education system, and specific measures that target migrant children, aim to provide comprehensive support to eliminate the educational disadvantage they experience. According to the authors, educational support should ideally include a combination of elements, such as linguistic and academic support, parental and community involvement, and intercultural education.

Heckmann (2008) also suggests that increased participation of migrant children in universal services for all children, irrespective of their background, can be beneficial. Access to inclusive high-quality Early Childhood Education and Care (ECEC) places has been found to alleviate the disadvantage faced by migrant children. For example, where pre-school is free, there are fewer gaps in attendance between immigrants' children and 'native' children (OECD \& EU 2015). OECD and EU (2015) data also show that children who attend pre-school have higher literacy results at 15 compared to those who did not come from a comparable socio-economic background. ECEC can help provide opportunities for migrant children to interact with the local community, learn host country languages in a pre-school setting, and equip children with social competencies in a structured setting (Brind et al. 2008; OECD 2010; Sirius 2014; Szalai 2011). A study by Crul and Schneider (2009) suggests that participation in early education, particularly at the age of two or three is effective in reducing the gap between children with migrant backgrounds and their native counterparts. Cebolla-Boado et al. (2013) also write that access to early childhood education and care (ECEC), such as pre-school and day care, coupled with the standardisation of curricula and teacher quality, are effective in reducing the disadvantage experienced by migrant students.

The importance of early ECEC for children of immigrants is also highlighted by Borgna and Contini (2014). The authors examined the 2006-2009 waves of the PISA on 15-year-old students across 17 Western European countries. In measuring the relative position of immigrant students within the 


\section{RAND Policy Brief}

achievement distribution of native students with the same socio-economic background, the authors found that children of immigrants are substantially disadvantaged. They concluded that in countries with high pre-school attendance rates or compulsory schooling from an early age, 15-year-old children of immigrants showed relatively small difference in educational outcomes compared with native students. This research also suggests that marginalisation in low-quality schools also contributes to the lower educational achievement of immigrant children. 
Table 1. Policy responses to support migrant children

\begin{tabular}{|l|l|l|}
\hline Level of policies & Education policies levels & $\begin{array}{l}\text { Policies addressing } \\
\text { perspectives of: }\end{array}$ \\
\hline - EU level & $\begin{array}{l}\text { - Education system } \\
\text { - National level }\end{array}$ & $\begin{array}{l}\text { - Sducators } \\
\text { - Local (or school) level }\end{array}$ \\
& $\begin{array}{l}\text { - Specific policies for } \\
\text { migrant children }\end{array}$ & - Parents \\
& & Society \\
\hline
\end{tabular}

In Section 5 we aim to summarise frameworks, focusing on how they are organised across policy domains and levels, as well as taking into account perspectives of relevant stakeholders and beneficiaries. It is worth noting, as highlighted in a number of studies, that coordinated action across several policy domains and stakeholders is required in order for policies to be efficient.

\section{Education policies supporting migrant children}

\subsection{Strategies for learning together}

A number of education policies, that is to say measures deployed within the context of the regular education system, have been shown to be efficient in alleviating disadvantage and increasing the educational success of migrant children. This section will focus on educational practices and policies, namely practices relating to educational segregation, transitioning to the labour market, and teaching and governance structures. Educational segregation across socio-economic characteristics has been found to contribute to polarised education systems and inequality in students' educational outcomes. Crul and Schneider (2009) argue that segregated schools limit the probability that a migrant child will continue to secondary education. As argued in the literature, the inclusive education system delivers better educational outcomes for all underachieving learners, including migrant children (see for instance Dumčius et al. 2013). As summarised in a report by Nusche (2009), educational segregation can be observed in three main forms:

- School catchment area systems

- School choice

- Ability groupings.

These mechanisms for school or class selection mechanisms can have either positive or negative impacts and are also context specific. We will look at policies relating to these three factors as well as inclusive learning practices affecting segregation, making mention of their benefits but also their apparent disadvantages.

\subsubsection{School catchment areas}

In countries with school catchment area systems, students are assigned to a local school in their neighbourhood. In this way, residential patterns are reflected in the school composition, with schools 
perceived to be of a better quality located in more affluent areas (which are also more expensive). Since migrant families are often underrepresented in these areas, they do not have access to these schools. Thus, a by-product of the segregated housing market can be a segregated education system (Nusche 2009; Szalai 2011).

\subsubsection{School choice}

Some countries have introduced school choice arrangements, giving parents a choice over the school their children will attend, irrespective of where they live (Nusche 2009). However, the evidence on the type of impact (positive and negative) of school choice is mixed. In addition, school choice does not necessarily mean that parents have complete freedom of choice in school selection. School choice arrangements may reinforce segregation if oversubscribed schools are able to select students based on their own criteria, e.g. distance to school or students' performance.

Parental selection of schools can also help in reinforcing segregation between migrant and non-migrant children. First, in free choice models, native upper- and middle-class families are usually the first to fill the better schools because they are well-informed and more mobile. By contrast, migrant parents may lack the requisite knowledge of the host country's educational system, the language competence or the resources to select the most appropriate school for their children (Dumčius et al. 2013). Secondly, migrant parents are less likely than native parents to move their children from schools with a large proportion of migrant children (Nusche 2009; Dumčius et al. 2013).

As already outlined in Section 3, OECD PISA data show that lower educational attainment can be linked to socio-economic disadvantage. ${ }^{15}$ This means that the presence of a large number of children at the class or school level whose parents (particularly the mother) have low education, have more impact on school achievement than a large presence of migrant children (Nusche 2009; OECD 2010). This prompts some researchers to suggest that classroom environments which provide a socio-economic mix would be a good step forward in ensuring better educational attainment among migrant children (OECD, 2010; OECD, 2013; Heckmann, 2008).

\subsubsection{Tracking and ability grouping}

Educational segregation can also come in a form of tracking or ability grouping, a very common education policy used in many countries at some stage of schooling. This approach streams pupils according to their perceived intellectual ability. In this way, curricula and teaching practices can be adapted to the specific needs, abilities and pace of learning of different groups. However, evidence shows that education systems with late selection of students to different ability tracks result in better educational attainment of migrant students (Crul \& Schneider 2009; Heckmann 2008). Migrant pupils in education systems using ability grouping tend to be tracked into groups with lower curricular standards and lower average performance levels. This, in turn, can hinder the learning experience of pupils who are streamed into the lowest tracks. Migrant students may be tracked into low ability tracks because their linguistic, social and cultural skills are usually (at least initially) lower than their native peers. This may mean that migrant children are locked into low ability groups before they have even had a chance to develop their

\footnotetext{
${ }^{15}$ Socio-economic disadvantage is defined by OECD researchers as having a low-educated mother.
} 
skills. In addition, compared with native children, migrant children are overrepresented in special education schools (Dumčius et al. 2013; Brind et al. 2008; Heckmann 2008; Nusche 2009).

Reviewing evidence on how to ensure that ability tracking does not hinder the educational opportunities of migrant children, Nusche (2009) found that several approaches can be effective. First of all, her study suggests that streaming migrant children into low tracks can be due to assessment mechanisms used by teachers. Equipping teachers with better assessment tools that take into account linguistic and cultural differences would potentially increase teachers' diagnostic competences and thus ensure more fair and transparent tracking. Secondly, postponing the age of tracking to give migrant pupils more time to develop their competences can also increase their chances of being streamed into high achieving groups. Nusche's (2009) review concludes that all children, migrant children and children with a low socioeconomic status, benefit from an education system that offers high curricular standards for all students, not just the most academically able students. Pekkarinen (2014) weighs the empirical evidence to suggest that tracking can hinder economic and educational mobility from one generation to another. Postponing tracking can help enhance social mobility, and could be perceived as more fair, but will not necessarily show improved attainment (Pekkarinen 2014).

\subsection{Policies supporting transition from education into the labour market}

As outlined in Section 3, migrant children, on average, have a higher risk of leaving school early. Research suggests that two approaches can be effective in tackling early school leaving: (1) additional support to encourage young people at risk to stay in school, and (2) support for the school-to-work transition or entry into higher education (Sirius 2014). Introducing flexibility in the education systems could support successful transition into the labour market, for example students could be provided with high quality second-chance programmes if they have not had the advantage of supportive learning environments earlier in their lives (Heckmann 2008; Sirius 2014). This would improve the learning outcomes of all learners, not just migrant learners. Sirius's (2014) research also suggests that young learners should be provided with an opportunity to learn through experience. This 'non-formal education' helps to develop personal and social skills and competences that, in turn, improve the labour market opportunities of migrant children.

\subsection{Policies focusing on teachers, teaching and school governance}

Studies highlight the importance of teaching and school governance in creating a nurturing school experience. OECD studies (for instance OECD 2005) have shown that the most important school-level factor influencing student outcomes is the quality of teaching. Other research (Brind et al. 2008; Sirius 2014) has demonstrated that strong school leadership and a school culture that is reflective and explicitly committed to equality play a pivotal role in creating a secure and enriching environment for children.

\subsubsection{Factors influencing effectiveness of teaching}

Teaching effectiveness may be influenced by several factors. First of all, smaller class sizes and higher teacher-student ratios allow more individualised support and the capacity to address specialised needs, thus providing more time and opportunities for each student to be more engaged. The impacts of reduced class sizes on migrant children and otherwise disadvantaged groups are significant (Björklund et al. 2005; 
Andersson 2007; Nusche 2009), while the evidence is mixed on its impact on mainstream pupils (Nusche 2009). Second, the improvement of teaching conditions through additional funding for teachers in challenging schools is also intended to improve teaching quality and teacher retention rates. Various countries have increased teacher remuneration with a view to improving their effectiveness. However, the evidence of its effectiveness is mixed, and little is known of its impact on migrant students' educational performance. Higher salaries for teachers in challenging schools help attract higher quality teachers, but in order to decrease turnover rates, salary increases would need to be significant (Nusche 2009:24).

\subsubsection{Increasing the proportion of teachers with a migrant background}

Some researchers suggest that increasing the proportion of teachers with a migrant background to fully represent the diversity in societies and classrooms can be effective in reducing the gap between migrant and non-migrant children (Nusche 2009; OECD 2014; Sirius 2014). This policy is based on assumptions that increasing the diversity of the teaching workforce would have a positive influence on migrant pupils' education outcomes. Migrant teachers could act as role models for migrant and non-migrant learners, and in doing so, could enhance the self-confidence and motivation of pupils. While there is little empirical evidence to support the claim that the demographic match between teachers and students improves students' educational outcomes, it is suggested that a shared demographic background 'decreases the cultural distance between migrants and school' (Heckmann 2008, 47). Recognising foreign-trained teachers' qualifications as well as providing them with support and up-skilling programmes are seen as important steps towards increasing the representation of people with a migrant background in the education profession (Schuster 2013). This would highlight the high societal value of teaching and, at the same time, would promote the inclusion of migrant teachers as qualified staff (Sirius 2014).

\subsubsection{Provision of mentoring to migrant children}

Mentoring schemes, which can take a variety of forms, could potentially help migrant children, by building up their confidence. Mentoring can provide opportunities for integration and support for all learners, not just migrant learners or other 'at risk' learners and can occur in the educational context or within the community. At the education level, trainee teachers with a migrant background in Germany work with migrant students in a relationship that is supposed to be mutually beneficial, enabling the trainee teachers to gain experience in the process (Heckmann 2008). Another example of teachers contributing to mentoring practices would be through homework centres where migrant or marginalised students are aided in their homework by their teachers or volunteers. This would be particularly suited to a context where parents cannot easily monitor their children's homework (Heckmann 2008). Community mentoring could take the shape of ethnic mentoring, whereby people with similar ethnic backgrounds who have completed education liaise with migrant children and their families by explaining the school and education system (e.g. the Moroccan Coaching Project) (Heckmann 2008).

\subsubsection{Recognising biases in schools}

Teachers' expectations and attitudes towards student learning, or biases in teachers' behaviour, could serve to have a negative impact on overall student performance. (Nusche 2009). 
These expectations and attitudes can manifest themselves through student-teacher interactions, grading and the assignment of students into ability groupings. Some experiments investigating grading bias have shown mixed evidence. While some German teachers displayed some grading bias in marking papers with Turkish names assigned to them, a similar experiment in the Netherlands did not yield the same result (De Paola and Brunello 2016). Nonetheless, some evidence was found in the Netherlands that ethnic majority teachers have lower expectations from ethnic minority students (De Paola and Brunello 2016), while teachers in the UK are half as likely to enter some ethnic minority students to the higher tier GCSE science and mathematics papers as they are white British children (Brind et al. 2008, 34).

The provision of training on diversity in the classroom could facilitate the professional development of school teachers and other school staff. Such professional training has been on offer in many European countries to prepare (would-be) teachers for teaching in a diverse classroom and to give them the confidence, skills and understanding required to meet the specific needs of migrant learners (see for instance: Brind et al. 2008; Eurydice 2004; Nusche 2009). There are also examples of in-service training, often undertaken as part of professional development programmes, which look to teach the value of diversity.

\subsubsection{Intercultural education}

Intercultural education centres on the inclusion of 'perspectives, examples and information from a variety of cultures and groups' in the curriculum and teaching materials (Nusche 2009:30).

The absence of migrants' experiences from the school curricula or textbooks, or the distorted presentation of migrants therein, can have a negative effect on migrant students' self-esteem according to Heckmann (2008) and can negatively affect their chances of school success. Assessing curriculum and teaching routines across European countries, Szalai (2011) reported that the dominant school practice is still based upon the values, norms and experiences of the native population. This, in turn, can lead to migrant children and ethnic minority pupils 'gradually develop[ing] a sense of inferiority, irrelevance and resentment' (167). A study by Brind et al. (2008, vi) suggests that 'intercultural education remains marginalised in policy terms.' As Nusche (2009) argues, this could be due to the scarce empirical evidence on the effectiveness of this approach on student learning, leading some researchers and policymakers to question such measures.

\subsection{Policies focusing on migrant children}

\subsubsection{Dedicating resources for migrant children education}

Allocating additional resources to schools with a high proportion of migrant students is a common policy approach. The rationale for this approach is twofold. First, the rationale dictates that extra resources could enable these schools to get on a more equal footing with other schools (Nusche 2009). Second, additional resources can be allocated to schools to allow them a degree of flexibility in catering for students' needs (Nusche 2009). In order to allocate resources efficiently, education policies need to determine target groups. Funding strategies can either adopt an integrated approach targeting all disadvantaged children (this strategy assumes that migrant status overlaps with low socio-economic status and high levels of poverty) or target the specific needs of migrant pupils. The provision of autonomy and guidance to 
schools and the management of available resources, such as identification of who should manage funding (e.g. regional-, local-, school-level, or combined management systems) are also key factors ensuring efficiency in funding. There is also strong evidence that focusing resources on early-years education produces the highest returns on investment. Although Early Education and Care programmes can have a positive impact and be more cost effective than remedial programmes at a later stage, investment in the subsequent levels of education is still beneficial for migrant pupils' educational achievement (Nusche 2009).

Apart from school-level funding, individual migrant pupils and their families may also receive additional subsidies to cover the cost of education-related expenditures, such as school transport and meals, materials and after-school activities. Usually, this additional funding is available on a means-tested basis, with migrant pupils being assessed alongside other students.

A study by Dumčius et al. (2013:9) recommends that 'schools should be given a reasonable level of autonomy.' According to authors, this autonomy would allow schools to better adapt and cater for the needs of their disadvantaged pupils, including migrant children.

\subsubsection{Addressing linguistic and cultural differences between schools and migrant families}

One of the challenges of integrating migrant children into education systems in Europe is related to the linguistic and cultural difficulties encountered between schools and migrant families. A Eurydice (2009) report summarises measures that EU Member States have undertaken to ensure and promote communication between schools and families. One of these measures, aimed at enhancing communication, is the provision of information about the school system in the mother languages of migrant families. Around two-thirds of EU Member States publish information on their school systems, typically covering all levels of education, from pre-primary to upper secondary. National education authorities are usually responsible for these publications, but in some countries these publications are also provided by local or school authorities. Publications are typically available in the languages of the most widely represented migrant groups.

The second measure to enhance communication between schools and parents reported in the Eurydice (2009) study is to use interpreters. In some countries, using interpreters is a statutory right for families, whereas in other countries it is adopted as a local initiative. The use of interpreters is not compulsory for migrant families but is often encouraged by the central authorities. When the use of interpreters is recommended, the national or regional public authorities provide schools with specific resources to serve this purpose. In other countries, where no national or local recommendations exist on the use of interpreters, the schools have to cover the cost of interpretation services from their own resources. These services are often provided by volunteers, teachers who speak the languages of migrant communities, and migrant parents. In several countries, migrant children are also used as interpreters for their families as well as other newly-arrived families speaking the same language.

The third common method used in European countries to welcome and guide migrant children is the use of resource persons acting as a liaison between schools and migrant families. Usually, this person is a member of the school staff or a staff member of the central or local education authorities. Their role includes helping pupils integrate and adapt to the school environment and supporting teachers in their educational activities. 
A study by Cebolla-Boado et al. (2013) looking at first- and second-generation immigrant children in Spain shows that the parenting quality, rather than differences across schools or broader institutional factors, has the largest influence on educational outcomes and the level of disadvantage. The authors argue that only a quarter of the existing variation in test scores among these children compared with native children can be explained at the school level.

\subsubsection{Approaches to learning host country language $(\mathrm{s})$}

An important part of education policies is language learning. According to the OECD, the integration of immigrant students can be facilitated by academic inclusion and language support (OECD 2015). This refers to both host country language learning as well as opportunities to maintain migrant languages. Multilingualism is seen to enhance intercultural skills and employment prospects in the globalised world (Szalai 2011; Sirius 2014). From the migrants' perspective, gaining skills in the host country languages is an essential step towards integration.

Nusche's review (2009) shows that language support for migrant students is most important and effective in early childhood as an early start in language learning improves school readiness. Provision of special language and literacy support before entering primary school helps to compensate migrant children for language disadvantages and allows them to achieve similar reading and writing skills as native children. Nevertheless, as Nusche's (2009) review shows, language learning is a long process and migrant children need systematic support to become proficient users of host societies' languages, in particular of the 'academic' language used in an education context.

Analysing policies adapted to facilitate language learning by newly-arrived school-age migrant children, Nusche's (2009) review concludes that there is little available empirical evidence on what constitutes 'best practice' in terms of migrant pupils' language learning. Based on their research, Dumčius et al. (2013) recommend that migrant children be integrated into mainstream classes and provided with additional language support within the regular class instruction. It appears that many countries withdraw migrant pupils from mainstream classes to offer them language support, an approach that can put migrant pupils at a disadvantage (Nusche 2009).

Nusche (2009) concludes that the available evidence points to some generic characteristics of successful programmes contributing to language learning. These are: the course programmes are developed based on the national curriculum for second language courses; language support is provided by teachers trained in second-language acquisition, offering high quality support to pupils; and the continuity of language learning throughout primary and secondary school.

This conclusion is in line with Directive (77/486/EEC) on the education of children of migrant workers, which states that Member States should provide migrant children with free tuition to help them settle into their host country. The results of a consultation of European stakeholders suggest that targeted language support should also be available to migrant learners during vocational training and apprenticeships (EC 2009). It is argued that this would facilitate inclusiveness and accessibility of VET to migrant learners. 


\subsubsection{Measures to learn and maintain home language(s)}

Brind et al. (2007) and Nusche (2009) argue that proficiency in their mother or migrant heritage language is important for migrant pupils. Mother tongue language support can help migrant children 'cement their sense of identity,' according to Eurydice (2004, 51). In addition, some work has shown that bilingualism has a number of benefits for individuals, including the development of cognitive skills and flexibility of thinking (De Paola and Brunello 2016). Migrant pupils' perception that their mother language and culture are valued can be beneficial to intercultural education and can assist in the integration of migrants with the host society by bridging the gap between school and home (Nusche 2009). In many European countries, migrant children are provided with opportunities to learn and maintain their mother language. Provision generally covers both primary and secondary education and is available to all migrant children, irrespective of their legal status and nationality. Home language tuition is organised either as a school-based activity or as an extracurricular lesson. When mother tongue tuition is organised and funded by the national educational authorities, it is typically provided outside normal school hours. As reported in the Eurydice (2009:19) report, 'tuition given outside the standard curriculum adds to pupils' school hours and can lead to feelings of rejection, mainly owing to the stigmatisation that attending such lessons can create.' In a small number of European countries, schools are encouraged to offer the home languages of migrant populations within their foreign languages curriculum. Nevertheless, Eurydice reports that in the majority of countries in Europe the priority for school children is to learn the language of instruction.

\subsubsection{Building partnerships with parents of migrant children}

Additional support can be also offered to parents of migrant children to facilitate participation in school life and integration within the school community. As briefly outlined in Section 3, parental integration can affect migrant pupils' attainment (Brind et al. 2008) and parental involvement in education can benefit student achievement and better education outcomes (Dumčius et al. 2013). However, due to a variety of factors (such as language difficulties, weak knowledge of the education system, or a lack of time/money), parents of migrant children are less likely to seek contact with schools and are less involved in their children's learning and school activities than native-born parents (see, for instance, Crul and Schneider 2009; Dumčius et al. 2013; Heckmann 2008).

In order to encourage migrant parents' engagement, Nusche (2009) argues that schools should proactively reach out to these parents and offer support. With the aim of building parental capacity to support their children, this support to parents can be organised through cultural mediators or social interpreters at parent/teacher consultations, as well as during home visits and other events. Sirius researchers (2014) argue that this support should be developed and funded through public services, rather than relying on voluntary organisations, as this would create a more welcoming environment and ensure better communication between the school and parents. At the same time, Crul and Schneider (2009) argue that migrant parents mostly offer socio-emotional support and not practical. Therefore, they suggest that schools (and teachers) should focus more on supporting migrant children on the practical aspects in order to compensate for this deficit.

It is commonly acknowledged that educational settings have a great role to play in the integration process of children with a migration background in host societies. At the same time, Nusche (2009) argues that 
professionals who are responsible for integration efforts (school teachers, nursery staff, specialised educators, etc.) are not well paid and these jobs, in general, are hardly considered as desirable career choices.

\subsection{Wider policies supporting migrant children}

Research shows that European and national-level anti-discrimination laws and policies are essential as they frame the organisation of the social system, including the education system. Researchers (e.g. Brind et al. 2008; Crul \& Schneider 2009; Sirius 2014) postulate that explicit anti-discrimination laws should be fully applicable to the education system on all grounds of discrimination, including nationality/citizenship/ethnicity, language, or residence status. Researchers argue that teachers, parents and students should be able to independently report discrimination in educational institutions and programmes, for instance in unfair hiring and promotion practices, refusals to allocate school places, or discriminatory tracking. Research by Heckmann (2008) also notes that 'discrimination is often one of the most important factors having impact on the achievements of migrant students.' The author argues that being 'denied support is the most significant form of discrimination in the education of migrant children' (8).

In addition, research indicates that migrant children's underachievement is the smallest in countries with low levels of economic inequality. This suggests that a comprehensive set of policies aimed at alleviating disadvantage also helps migrant students in achieving better education outcomes (Heckmann 2008).

\section{Concluding remarks}

This policy brief aimed to outline the challenges facing migrant children in education across Europe as well as some policies that could contribute towards remedying some of the disadvantages they experience. Migrant children under the age of 15 represent approximately five per cent of the EU population. Large variations in the distribution of the migrant child population exist across Member States. ${ }^{16}$ In addition, there is also variation in the proportion of children among the foreign-born population in some Member States. ${ }^{17}$ In this context, it is important to understand that each Member State has a different experience in terms of migration and that there is no 'silver bullet' or one-size-fits-all policy measure or initiative to accommodate children with a migrant background into the classroom.

Across the EU, children with a migrant background tend (both first-, second- and higher-ordergeneration), on average, to perform less well in school and are more likely to be early school leavers than their native counterparts. A number of intersecting reasons may have some bearing on this trend, including potential socio-economic disadvantage, social isolation and issues with the language of instruction. It is worth noting that some of these challenges are not endemic to migrants. While cultural and linguistic factors can play a role in a child's success, and their social and educational integration and progression, other factors, such as socio-economic disadvantage are critical and should be given due attention.

\footnotetext{
${ }^{16}$ With a reported 18.5 percentage point difference between Luxembourg, at the higher end, and Czech Republic (Eurostat indicator migr_pop3ctb).

${ }^{17}$ For example, migrant children represent almost 38 per cent in Romania and 10.7 per cent in Poland.
} 
Therefore, a range of complementary policies and approaches are possible at different levels (national, local, etc.) and need to include a range of stakeholders (for example, school administrators, educators, parents, politicians, third sector). This policy brief highlighted some levers and policy options for consideration that could enable success and perhaps reduce attrition in education among migrant children. These measures include providing instruction in the host language, building and maintaining relationships with migrant children's parents, dedicating more resources to schools with a high concentration of migrants to allow them to be flexible to students' needs, ensuring access to ECEC and disincentivising segregation practices linked to ability and socio-economic factors.

Some EU Member States have already adopted measures focused on the integration of migrant children within their education system. Clearly, initiatives within the education system can have effects on migrant children's educational success, helping migrant children to reach their full potential. However, an ever growing evidence base on what works for migrant children's education is needed to enable education systems, practitioners and migrant families to effectively respond to the challenges facing migrant children across the European Union. 


\section{References}

Algan, Yann, Christian Dustmann, Albrecht Glitz \& Alan Manning. 2010. 'The economic situation of first and second-generation immigrants in France, Germany and the United Kingdom.' The Economic Journal 120 (February): F4-F30. doi: 10.1111/j.1468-0297.2009.02338.

Anderson, Bridget \& Scott Blinder. 2015. 'Briefing: Who counts as a migrant? Definitions and their Consequences $-4^{\text {th }}$ Revision.' The Migration Observatory at the University of Oxford, 25 August. As of 26 August 2016: http:/www.migrationobservatory.ox.ac.uk/sites/files/migobs/Briefing\%20-

\%20Who\%20Counts\%20as\%20a\%20Migrant.pdf

Andersson, C. 2007. Teacher Density and Student Achievement in Swedish Compulsory Schools. Uppsala: Department of Economics, Uppsala Universitet. 2007:5. As of 26 August 2016: https://uu.diva-portal.org/smash/get/diva2:53132/FULLTEXT01.pdf

Arnot, Madeleine \& Loraine Gelsthorpe. 2014. 'Migrant children: the litmus test of our education system.' University of Cambridge, 14 February. As of 26 August 2016:

http://www.cam.ac.uk/research/features/migrant-children-the-litmus-test-of-our-education-system

BBC News. 2016. 'Migrant crisis: Migration to Europe explained in seven charts.' BBC News, 4 March. As of 26 August 2016: http://www.bbc.com/news/world-europe-34131911

Björklund, Anders, Melissa A. Clark, Per-Anders Edin, Peter Fredriksson \& Alan B. Kreuger. 2005. The Market Comes to Education in Sweden: An Evaluation of Sweden's Surprising School Reforms. New York: Russell Sage Foundation.

Brind, Tom, Caroline Harper \& Karen Moore. 2008. 'Education for migrant, minority and marginalised children in Europe. A report commissioned by the Open Society Institute's Education Support Programme.' Open Society Foundations, 31 January. As of 26 August https://www.opensocietyfoundations.org/sites/default/files/review_20080131.pdf

Borgna, Camilla \& Dalit Contini. 2014. 'Migrant Achievement Penalties in Western Europe: Do Educational Systems Matter?' European Sociological Review 30 (5): 670-683.

Breuil-Genier, Pascale, Catherine Borrel \& Bertrand Lhommeau. 2011. 'Les immigrés, les descendants d'immigrés et leurs enfants.' Insee. As of 26 August http://www.insee.fr/fr/ffc/docs_ffc/ref/FPORSOC11d_VE22Immig.pdf

Héctor Cebolla-Boado, Amparo González-Ferrer \& Yasemin Soysal. 2013. The Interplay Between Families and Schools: Immigrant and Native Differentials in Educational Outcomes. Madrid: Juan March Institute, Center for Advanced Study in the Social Sciences (CEACS). 2013/280. As of 26 August 2016: http://digital.csic.es/bitstream/10261/93173/1/Families\%20and\%20school.pdf

Crul, Maurice \& Jens Schneider. 2009. 'The Second Generation in Europe: Education and the Transition to the Labor Market.' Migration Policy Institute. As of 26 August 2016: http://www.migrationpolicy.org/research/second-generation-europe-education-and-transition-labor-market

Council Directive 77/486/EEC of 25 July 1977 on the education of the children of migrant workers. As of 26 August 2016: http://eur-lex.europa.eu/LexUriServ/LexUriServ.do?uri=CELEX:31977L0486:EN:HTML

Department for Education and Skills. 2006. 'Ethnicity and Education: The Evidence on Minority Ethnic Pupils aged 5-16. Research Topic Paper.' National Archives. As of 26 August 2016: http://webarchive.nationalarchives.gov.uk/20080530183443/http://dcsf.gov.uk/research/data/uploa dfiles/0208-2006dom-en.pdf

DG EAC. 2009. “Migration \& Mobility: Challenges and opportunities for EU education systems”: The Green Paper and the results of the public consultation. European Union. As of 26 August 2016: http://cor.europa.eu/en/Archived/Documents/3e46ba55-d6b4-45f8-9969-fdf556f1ee22.pdf 
Dumčius, Rimantas, Hanna Siarova, Ides Nicaise, Jana Huttova \& Indré Balčaitè. 2013. Study on educational support for newly arrived migrant children. Luxembourg: Publications Office of the European Union.

Dustmann, Christian, Tommaso Frattini \& Gianandrea Lanzara. 2012. 'Educational Achievement of SecondGeneration Immigrants: An International Comparison.’ Economic Policy 27: 143-185.

Eurodiaconia. 2014. 'The integration of children and families with a migration background. An overview of projects among Eurodiaconia members.' Eurodiaconia. As of 26 August 2016:

http://eurodiaconia.org/wordpress/wp-content/uploads/2015/08/mapping-document-on-child-and-familyintegration1.pdf

European Commission. 2009. 'Commission staff working document: Results of the consultation on the education of children from a migrant background.' European Parliament. As of 26 August 2016: http://www.europarl.europa.eu/registre/docs_autres_institutions/commission_europeenne/sec/2009/ 1115/COM_SEC(2009)1115_EN.pdf

European Commission. 2015. 'Immigration in the EU.' Eurostat 10/6/2015. As of 26 August 2016: http://ec.europa.eu/dgs/home-affairs/e-library/docs/infographics/immigration/migration-in-euinfographic_en.pdf

European Communities. 2008. 'Green Paper: Migration and mobility: challenges and opportunities for EU education systems. European Union $\operatorname{COM}(2008) 423$ final, $\{\operatorname{SEC}(2008) 2173\}$. As of 26 August 2016: http://eur-lex.europa.eu/LexUriServ/LexUriServ.do?uri=COM:2008:0423:FIN:EN:PDF

Eurostat. 2015a. Statistics data based on the variable 'Population on 1 January by five year age group, sex and country of birth [migr_pop3ctb].' Eurostat. As of 26 August 2016: http://appsso.eurostat.ec.europa.eu/nui/show.do?dataset=migr_pop3ctb\&lang=en

Eurostat. 2015b. Statistics data based on the variable 'Population on 1 January by five year age group, sex and country of birth [migr_pop3ctb_under15].' As of 26 August 2016: http://appsso.eurostat.ec.europa.eu/nui/show.do?dataset=migr_pop3ctb\&lang=en

Eurydice. 2004. Integrating Immigrant Children into Schools in Europe. Brussels: Eurydice.

Eurydice. 2009. Integrating immigrant children into schools in Europe: Measures to foster communication with immigrant families and heritage language teaching for immigrant children. Brussels: Eurydice.

Fossati, Flavia. 2011. 'The effect of integration and social democratic welfare states on immigrants' educational attainment: a multilevel estimate.' Journal of European Social Policy 21: 391-412.

Heath, Anthony F., Catherine Rothon \& Elina Kilpi. 2008. 'The second generation in Western Europe: education, unemployment, and occupational attainment.' Annual Review of Sociology 34: 211-235.

Heckmann, Friedrich. 2008. 'Education and migration: Strategies for integrating migrant children in European schools and societies: A synthesis of research findings for policy-makers.' NESSE. As of 26 August 2016: http://www.nesse.fr/nesse/activities/reports/activities/reports/education-and-migration-pdf.

Insee (Institut national de la statistique et des études économiques). 2011. 'Données détaillées des statistiques d'état civil sur les naissances en 2010.' Insee. As of 26 August 2016: http://www.insee.fr/fr/themes/detail.asp?ref_id=ir-sd20101

Jensen, Peter. 2015. 'Immigrants in the classroom and effects on native children.' IZA World of Labor. As of 26 August 2016: http://wol.iza.org/articles/immigrants-in-classroom-and-effects-on-native-children.pdf

Jakubowski, Maciej. 2011. 'How are school systems adapting to increasing numbers of immigrant students?' PISA in Focus 2011/11. As 20 of 2016 : http://www.oecd.org/pisa/pisaproducts/pisainfocus/49264831.pdf

Kulu, Hill \& Amparo González-Ferrer. 2014. 'Family dynamics among immigrants and their descendants in Europe: current research and opportunities.' European Journal of Population 30 (4): 411-435.

Nouwen, Ward, Noel Clycq \& Daniela Ulična. 2015. 'Reducing the Risk that Youth with a Migrant Background in Europe will Leave School Early.' Sirius Network Policy Brief Series 6. As of 26 August 2016: 
http://www.sirius-migrationeducation.org/wp-content/uploads/2015/02/SIRIUS-EarlySchoolLeavingFINAL.pdf

Nusche, Deborah. 2009. 'What Works in Migrant Education? A Review of Evidence and Policy Options.' OECD Education Working Papers 22, OECD Publishing. As of 26 August 2016: http://dx.doi.org/10.1787/227131784531.

OECD. 2005. 'Teachers matter: attracting, developing and retaining effective teachers.' OECD. As of 26 August 2016: https://www.oecd.org/edu/school/34990905.pdf

OECD. 2010. 'Equal opportunities? The labour market integration of the children of immigrants.' OECD, 12 May. As of 26 August 2016:

http://www.oecd-ilibrary.org/social-issues-migration-health/equal-opportunities_9789264086395-en

OECD. 2013. 'Who are the strong performers and successful reformers in education?' Pisa in Focus 34 . As of 26 August 2016: http://www.oecd-ilibrary.org/education/who-are-the-strong-performers-and-successfulreformers-in-education_5k3wb8k5vr7l-en

OECD. 2014. 'TALIS 2013 Results: An International Perspective on Teaching and Learning.' OECD, 25 June. As of 26 August 2016: http://www.oecd-ilibrary.org/education/talis-2013-results_9789264196261-en

OECD. 2015. 'Can schools help to integrate immigrants?' PISA in Focus 57. As of 26 August 2016: http://www.oecd-

ilibrary.org/docserver/download/5jrqj7vk0jhk.pdf?expires=1467621956\&id=id\&accname= guest\&checksum=3057AC3A0C3552EC963584A718AEB827

OECD and EU. 2015. 'Indicators of Immigrant Integration 2015: Settling In.' OECD, 2 July. As of 26 August 2016:

http:/www.oecd-ilibrary.org/social-issues-migration-health/indicators-of-immigrant-integration-2015-settlingin_9789264234024-en

Office for National Statistics. 2014. 'Births in England and Wales by parents' country of birth, 2013.' Office for National Statistics. As of 26 August 2016: http://www.ons.gov.uk/ons/dcp171778_375070.pdf

Pekkarinen, Tuomas. 2014. 'School tracking and intergenerational social mobility: Postponing school tracking can increase social mobility without significant adverse effects on educational achievement.' IZA World of Labor. As of 26 August 2016: http://wol.iza.org/articles/school-tracking-and-intergenerational-social-mobility.pdf

Robards, James, Ann Berrington \& Teresa McGowan, eds. 2015. The fertility of recent migrants to England and Wales: interrelationships between migration and birth timing. Southampton: ESRC Centre for Population Change Working Papers, 65. As of 26 August 2016: http://eprints.soton.ac.uk/377909/1/2015_WP65_The_fertility_of_recent_migrants_to_England_and_Wales. pdf

Schuster, Anke, Maria Vincenza Desiderio, Giuliana Urso. 2013. Recognition of Qualifications and Competences of Migrants. Brussels: International Organization for Migration.

Schneeweis, Nicole. 2011. 'Educational institutions and the integration of migrants.' Journal of Population Economics 24: 1281-1308.

Sirius. 2014. 'A clear agenda for migrant education in Europe.' Sirius. As of 26 August 2016: http://www.sirius-migrationeducation.org/wp-content/uploads/2014/11/Agenda-andRecommendations-for-Migrant-Education.pdf

Strand, Steve, Lars Malmberg, \& James Hall. 2015. 'English as an Additional Language (EAL) and educational achievement in England: An analysis of the National Pupil Database.' Education Endowment Foundation, 29 January. As of $26 \quad$ August 2016: https://educationendowmentfoundation.org.uk/uploads/pdf/EAL_and_educational_achievement2.p $\mathrm{df}$ 
Szalai, Julia, ed. 2011. 'Contested issues of social inclusion through education in multi-ethnic communities across Europe.' Budapest: EDUMIGROM.

Tromans, Nicola, Eva Natamba, Julie Jefferies. 2009. 'Have women born outside the UK driven the rise in the UK births since 2001?’ Population Trends 136: 28-42.

Zumpe, Jo, Oliver Dormon, Julie Jefferies. 2012. 'Childbearing among UK born and non-UK born women living in the UK.' Office for National Statistics, 25 October. As of 26 August 2016: http://webarchive.nationalarchives.gov.uk/20160105160709/http://www.ons.gov.uk/ons/dcp17176 6_283876.pdf 